CrossMark \& click for updates

Cite this: Chem. Commun., 2016, 52,594

Received 14th September 2015, Accepted 2nd November 2015

DOI: $10.1039 / c 5 c c 07698 f$

www.rsc.org/chemcomm

\section{A new type of oxidative addition of an iodoarene to a $\mathrm{Pd}(\mathrm{II})$ complex $\dagger$}

\author{
Inmaculada Vicente-Hernández, ${ }^{a}$ María-Teresa Chicote, ${ }^{a}$ José Vicente* ${ }^{{ }^{a}}$ and \\ Delia Bautista ${ }^{\mathrm{b}}$
}

\begin{abstract}
Oxidative addition of $\mathrm{N}$-(2-iodophenyl)formamide to $\mathrm{Pd}(\mathrm{dba})_{2}$ ( $\mathrm{dba}=$ dibenzylideneacetone) in the presence of 4,4'-ditertbutyl2,2'-bipyridine ( $\left.{ }^{t} \mathrm{Bubpy}\right)$ produces $\left[\mathrm{Pd}\left(\mathrm{C}_{6} \mathrm{H}_{4} \mathrm{NHCHO}-2\right)\left({ }^{t} \mathrm{Bubpy}\right)\right](1)$ which inserts 2-iodophenyl isocyanide to give $\left[\mathrm{Pd}\left\{\mathrm{C}\left(=\mathrm{NC}_{6} \mathrm{H}_{4} \mathrm{I}-\right.\right.\right.$ 2) $\left.\mathrm{C}_{6} \mathrm{H}_{4} \mathrm{NHCHO}-2\right\}$ I('Bubpy)] (2). Dehydroiodination of 2 with $\mathrm{Tl}(\mathrm{acac})$ (acacH = acetylacetone) gives the stable $\mathrm{Pd}(\mathrm{Iv})$ complex OC-6-35[Pd $\left.\left\{\mathrm{C}, \mathrm{N}, \mathrm{N}-\mathrm{C}\left(=\mathrm{NC}_{6} \mathrm{H}_{4}-2\right) \mathrm{C}_{6} \mathrm{H}_{4} \mathrm{NCHO}-2\right\} \mid\left({ }^{t} \mathrm{Bubpy}\right)\right]$ (4) likely resulting from the spontaneous oxidative addition of the $\mathrm{I}-\mathrm{Ar}$ moiety present in the unstable intermediate $\mathrm{Pd}(\mathrm{II})$ complex $\left[\mathrm{Pd}\left\{\mathrm{C}, \mathrm{N}-\mathrm{C}\left(=\mathrm{NC}_{6} \mathrm{H}_{4} \mathrm{I}-\right.\right.\right.$ 2) $\left.\mathrm{C}_{6} \mathrm{H}_{4} \mathrm{NCHO}-2\right\}$ ('Bubpy)] (3). The crystal structure of 4 shows various $\mathrm{C}-\mathrm{H} \ldots \mathrm{O}$ hydrogen bonds resulting in chains of dimers stacked along the $a$ axis.
\end{abstract}

The important role of $\mathrm{Pd}$-catalyzed $\mathrm{C}-\mathrm{C}$ cross coupling reactions in organic synthesis is very well known. ${ }^{1}$ These reactions involve $\operatorname{Pd}(0)^{2,3}$ or $\operatorname{Pd}(\mathrm{II})^{4}$ precatalysts and, in most cases, the catalyst is $\mathrm{Pd}$ metal or a $\operatorname{Pd}(0)$ complex formed from the precatalyst. However, in some cases in which the precatalyst is a $\mathrm{Pd}(\mathrm{II})$ complex, experimental $^{3,5,6}$ and theoretical ${ }^{7}$ studies suggested a $\mathrm{Pd}(\mathrm{II}) / \mathrm{Pd}(\mathrm{Iv})$ catalytic cycle as an alternative to the usual $\operatorname{Pd}(0) / \operatorname{Pd}(\mathrm{II})$ one. The main objections to this proposal, when an aryl halide is involved (Heck, Suzuki-Miyaura, Sonogashira, Stille, etc. coupling reactions), were that (1) the necessary oxidative addition of the haloarene to $\operatorname{Pd}(\mathrm{II})$ had no experimental support, and (2) the $\operatorname{Pd}(\mathrm{Iv})$ intermediate formed during catalysis had not been detected. However, we have recently given experimental evidence against these two objections by isolating the $\mathrm{Pd}(\mathrm{Iv})$ oxidative addition product (A, Scheme 1) of an aryl iodide to a $\operatorname{Pd}(\mathrm{II})$ complex, ${ }^{8,9}$ and detecting the $\mathrm{Pd}(\mathrm{IV})$ complex in a Heck-type catalytic reaction. ${ }^{10}$

The easy formation of complexes $\mathbf{A}$ and $\mathbf{B}$ (Scheme 1) was explained as a consequence of the coordination of the

\footnotetext{
${ }^{a}$ Grupo de Química Organometálica, Departamento de Química Inorgánica,

Facultad de Quimica, Universidad de Murcia, Apartado 4021, Murcia, 30071, Spain.E-mail: jvs1@um.es, mch@um.es

${ }^{b}$ SAI, Universidad de Murcia, Spain.E-mail: dbc@um.es

$\dagger$ Electronic supplementary information (ESI) available: Experimental and spectroscopic data. CCDC 1414698. For ESI and crystallographic data in CIF or other electronic format see DOI: 10.1039/c5cc07698f
}

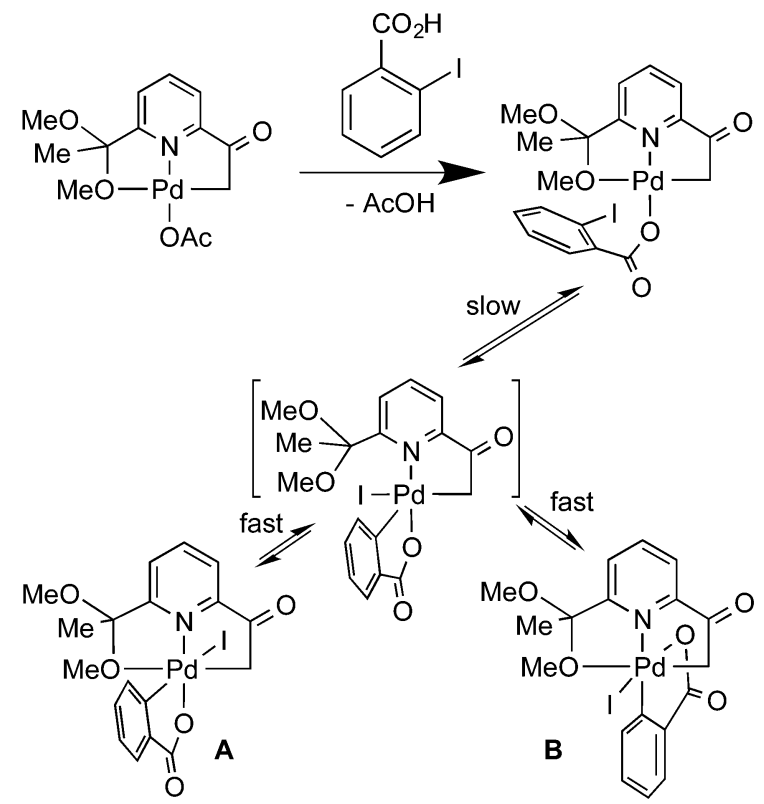

Scheme 1 Synthesis of complex A.

2-iodobenzoato ligand that would bring the iodine and Pd atoms close to each other. ${ }^{9}$ We have used the same coordinationassisted oxidative addition of the 2-iodobenzoato ligand with other Pd(II) complexes. ${ }^{8}$

In this work we describe a new way of assistance of the oxidative addition of an aryl halide to a Pd(II) complex. It involves the insertion of an isocyanide into the Pd-C bond of an aryl $\mathrm{Pd}(\mathrm{II})$ complex (1 in Scheme 2), a very well known process ${ }^{11}$ that has been recently reviewed. ${ }^{12}$ The rising interest of $\operatorname{Pd}(\mathrm{Iv})$ chemistry in synthesis and catalysis is very well established. ${ }^{13}$

Complex 1 (Scheme 2) was obtained by the oxidative addition of $\mathrm{N}$-(2-iodophenyl)formamide ${ }^{14}$ to $\mathrm{Pd}_{2}(\mathrm{dba})_{3} \cdot \mathrm{dba}$ ("Pd(dba) $)_{2}$ ", $\mathrm{dba}=$ dibenzylideneacetone $)$ in the presence of ${ }^{t}$ Bubpy $(1: 1: 1$, toluene, room temperature, $5 \mathrm{~h}, 80 \%)$. Insertion of 2-iodophenyl isocyanide into the $\mathrm{Pd}-\mathrm{C}$ bond of $\mathbf{1}$ produced the iminobenzoyl complex 2 (1:1, $\mathrm{CH}_{2} \mathrm{Cl}_{2}$, room temperature, $\left.20 \mathrm{~min}, 89 \%\right)$ 

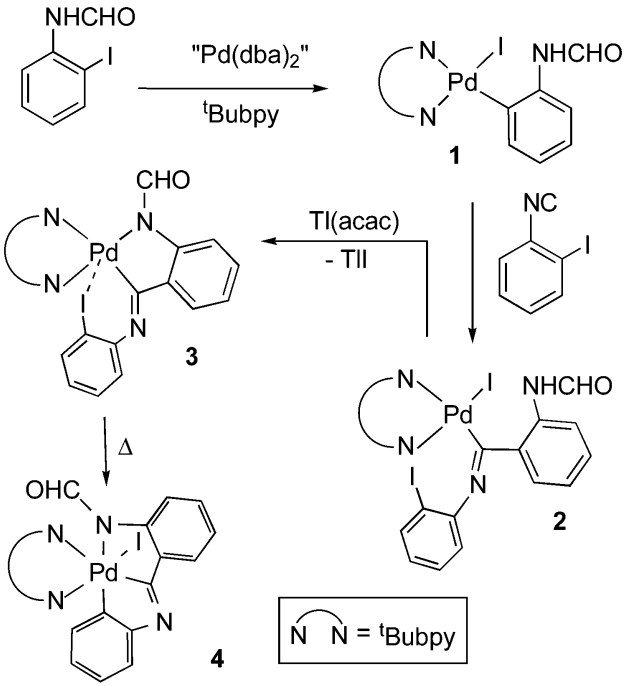

Scheme 2 Synthesis of complex 4

which decomposed upon heating in solution or even upon standing at room temperature to give the almost quantitative amount of $\left[\mathrm{PdI}_{2}\left({ }^{t} \mathrm{Bubpy}\right)\right]$ along with an unresolved mixture of products. This result suggested that an unstable diiodopalladium(rv) complex, probably [ $\mathrm{Pd}\left\{\mathrm{C}, \mathrm{N}, \mathrm{N}-\mathrm{C}\left(=\mathrm{NC}_{6} \mathrm{H}_{4}-2\right) \mathrm{C}_{6} \mathrm{H}_{4} \mathrm{NHCHO}-2\right\} \mathrm{I}_{2}\left({ }^{t}\right.$ Bubpy $\left.)\right]$, formed from the oxidative addition to $\mathrm{Pd}(\mathrm{II})$ of the I-iminobenzoyl fragment. The great instability of the only known diiodo $\mathrm{Pd}(\mathrm{Iv})$ organometallic complex has been previously reported. ${ }^{15}$ In order to avoid this decomposition process we decided to dehydroiodinate complex 2 with $\mathrm{Tl}(\mathrm{acac})$ (acacH = acetylacetone) but, instead of the expected complex 3, spontaneous formation of the $\operatorname{Pd}(\mathrm{Iv})$ complex 4 occurred, containing a stabilizing ${ }^{6,16}$ pincer ligand. The isolated reaction mixture $(1: 1$, acetone, $1 \mathrm{~h}$, room temperature) was shown by ${ }^{1} \mathrm{H}$ NMR to contain mainly 4 , while intermediate 3 , which we assume to be a minor component of the mixture, could not be isolated even from a 15 min reaction. Pure complex 4 was isolated in $75 \%$ yield at $50{ }^{\circ} \mathrm{C}$ for $5 \mathrm{~h}$ but also after a couple of days standing at room temperature.

The oxidative addition reactions of $\mathrm{R}-\mathrm{X}(\mathrm{R}=$ alkyl $)$ compounds to $\operatorname{Pd}(\mathrm{II})$ complexes lead to cis-, trans- or mixtures of both $\operatorname{Pd}(\mathrm{Iv})$ isomers depending on the nature of $\mathrm{R}^{17}{ }^{17}$ In the case of the oxidative addition of 2-iodobenzoate (Scheme 1), the ${ }^{1} \mathrm{H}$ NMR spectrum of the reaction mixture showed an equilibrium between both isomers $\mathbf{A}$ and $\mathbf{B}$, the later characterized by X-ray crystallography. The presence of a weakly coordinating group $(\mathrm{MeO})$ may be responsible for the easy conversion of both isomers through a pentacoordinate intermediate, ${ }^{9}$ which in the present case seems not to be available (even at $50{ }^{\circ} \mathrm{C}$ for $5 \mathrm{~h}$ ) since both the ${ }^{t}$ Bubpy and the $\mathrm{C}^{\wedge} \mathrm{N}$ ligands form robust palladacycles. Therefore, the results of the three known reported cases suggest that the intramolecular oxidative addition of aryl iodides to Pd(II) leads to the cis isomer that can isomerize to the trans isomer if a weakly coordinating group facilitates the process.

According to NMR data, complexes $\mathbf{1}$ and $\mathbf{2}$ form as mixtures of isomers as is also the case of the starting compound $N$-(2-iodophenyl)formamide. ${ }^{14,18}$

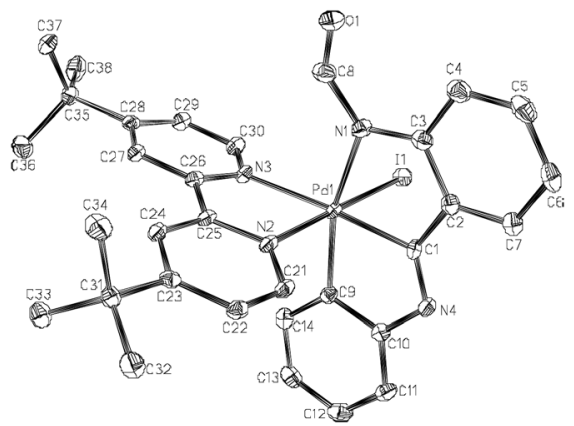

Fig. 1 Ortep drawing (50\% probability ellipsoids) of complex $4 \cdot \mathbf{C H}_{\mathbf{2}} \mathrm{Cl}_{\mathbf{2}}$.

The crystal structure of $\mathbf{4} \cdot \mathbf{C H}_{\mathbf{2}} \mathbf{C l}_{\mathbf{2}}$ (Fig. 1) has been determined by X-ray diffraction methods. It shows the Pd atom in a rather distorted octahedral environment. The greater trans influence of carbon with respect to nitrogen donor ligands is observed in the Pd- $\mathrm{N}_{t \text { Bubpy }}$ bond distances (2.1763(18) vs. 2.0767(19) $\AA$ ). The Pd-I bond distance (2.5992(3) ̊) is similar to that in the only other monoiodo Pd(Iv) complex structurally characterized having iodo trans to nitrogen $(2.5902(3) \AA) .{ }^{19}$ A chain of dimers forms along the $a$ axis through various $\mathrm{C}-\mathrm{H} \cdots \mathrm{O}$ hydrogen bonds.

Very few crystal structures of $\operatorname{Pd}(\mathrm{Iv})$-iodo complexes have been reported, namely those of one triiodo ${ }^{20}$ and three monoiodo $^{9,19,21}$ derivatives.

In conclusion, we show an alternative way to oxidatively add an iodoarene to a $\mathrm{Pd}(\mathrm{II})$ complex to give a very stable aryl $\mathrm{Pd}(\mathrm{Iv})$ complex through insertion of 2-iodophenyl isocyanide into the C-Pd bond of an aryl Pd(II) complex. This work opens a new research line that, provided the appropriate aryl $\mathrm{Pd}(\mathrm{II})$ complexes and 2-iodoarylisocyanides (or related reagents) were used, could lead to interesting organic products through unstable $\mathrm{Pd}(\mathrm{Iv})$ intermediates.

We thank the Ministerio de Ciencia e Innovación (Spain), FEDER (Project CTQ2011-24016), and Fundación Séneca (CARM, Murcia, Spain; 04539/GERM/06) for financial support.

\section{Notes and references}

1 X.-F. Wu, P. Anbarasan, H. Neumann and M. Beller, Angew. Chem., Int. Ed., 2010, 49, 9047-9050; A. Zapf and M. Beller, Chem. Commun., 2005, 431-440; W. A. Herrmann, C. Brossmer, K. Öfele, C. P. Reisinger, T. Priermeier, M. Beller and H. Fischer, Angew. Chem., Int. Ed. Engl., 1995, 34, 1844-1848.

2 C. Amatore and A. Jutand, Acc. Chem. Res., 2000, 33, 314-321; G. T. Crisp, Chem. Soc. Rev., 1998, 27, 427-436.

3 L. Xue and Z. Lin, Chem. Soc. Rev., 2010, 39, 1692-1705.

4 D. A. Alonso and C. Najera, Chem. Soc. Rev., 2010, 39, 2891-2902; I. P. Beletskaya, A. N. Kashin, N. B. Karlstedt, A. V. Mitin, A. V. Cheprakov and G. M. Kazankov, J. Organomet. Chem., 2001, 622, 89-96; V. P. W. Böhm and W. A. Herrmann, Chem. - Eur. J., 2001, 7, 4191-4197; J. E. Bollinger, O. Blacque and C. M. Frech, Chem. - Eur. J., 2008, 14, 7969-7977; M. R. Eberhard, Org. Lett., 2004, 6, 2125-2128; M. Nowotny, U. Hanefeld, H. van Koningsveld and T. Maschmeyer, Chem. Commun., 2000, 1877-1878; E. Peris, J. A. Loch, J. Mata and R. H. Crabtree, Chem. Commun., 2001, 201-202; G. Ren, X. Cui, E. Yang, F. Yang and Y. Wu, Tetrahedron, 2010, 66, 4022-4028; C. Rocaboy and J. A. Gladysz, New J. Chem., 2003, 27, 39-49; M. A. K. Vogel, C. B. W. Stark and I. M. Lyapkaloc, Adv. Synth. Catal., 2007, 349, 1019-1024. 
5 A. Avila-Sorrosa, F. Estudiante Negrete, S. Hernández Ortega, A. Toscano and D. Morales Morales, Inorg. Chim. Acta, 2010, 363, 1262-1268; R. Gerber, O. Blacque and C. M. Frech, ChemCatChem, 2009, 1, 393; S. Sjovall, O. F. Wendt and C. Andersson, J. Chem. Soc., Dalton Trans., 2002, 1396-1400; Y. Ye, N. D. Ball, J. W. Kampf and M. S. Sanford, J. Am. Chem. Soc., 2010, 132, 14682-14687.

6 D. Shabashov and O. Daugulis, J. Am. Chem. Soc., 2010, 132, 3965-3972.

7 O. Blacque and C. M. Frech, Chem. - Eur. J., 2010, 16, 1521-1531; A. Sundermann, O. Uzan and J. M. L. Martin, Chem. - Eur. J., 2001, 7, 1703-1711; Y. Dang, S. Qu, J. W. Nelson, H. D. Pham, Z.-X. Wang and X. Wang, J. Am. Chem. Soc., 2015, 137, 2006-2014.

8 A. J. Martinez-Martinez, M. T. Chicote, D. Bautista and J. Vicente, Organometallics, 2012, 31, 3711-3719.

9 J. Vicente, A. Arcas, F. Julia-Hernandez and D. Bautista, Angew. Chem., Int. Ed. Engl., 2011, 50, 6896-6899.

10 F. Juliá-Hernández, A. Arcas and J. Vicente, Chem. - Eur. J., 2012, 18, 7780-7786.

11 M.-J. Oliva-Madrid, J. A. García-López, I. Saura-Llamas, D. Bautista and J. Vicente, Organometallics, 2014, 33, 19-32; A. Abellan-Lopez, M. T. Chicote, D. Bautista and J. Vicente, Dalton Trans., 2014, 43, 592-598; J. Vicente, J.-A. Abad, M.-J. Lopez-Saez, W. Förtsch and P. G. Jones, Organometallics, 2004, 23, 4414-4429.

12 V. P. Boyarskiy, N. A. Bokach, K. V. Luzyanin and V. Y. Kukushkin, Chem. Rev., 2015, 115, 2698-2779.
13 J. J. Topczewski and M. S. Sanford, Chem. Sci., 2015, 6, 70-76; L. M. Xu, B. J. Li, Z. Yang and Z. J. Shi, Chem. Soc. Rev., 2010, 39, 712-733; P. Sehnal, R. J. K. Taylor and I. J. S. Fairlamb, Chem. Rev., 2010, 110, 824-889; A. J. Canty, A. Ariafard, B. F. Yates and M. S. Sanford, Organometallics, 2015, 34, 1085-1090; C. P. Park, J. H. Lee, K. S. Yoo and K. W. Jung, Org. Lett., 2010, 12, 2450-2452; K. Muñiz, Angew. Chem., Int. Ed., 2009, 48, 9412-9423; N. M. Camasso, M. H. Perez-Temprano and M. S. Sanford, J. Am. Chem. Soc., 2014, 136, 12771-12775.

14 T. Kesharwani, A. K. Verma, D. Emrich, J. A. Ward and R. C. Larock, Org. Lett., 2009, 11, 2591-2593.

15 A. J. Canty, M. C. Denney, B. W. Skelton and A. H. White, Organometallics, 2004, 23, 1122-1131.

16 J. Vicente, A. Arcas, F. Julia-Hernandez and D. Bautista, Chem. Commun., 2010, 46, 7253-7255.

17 A. J. Canty, J. L. Hoare, N. W. Davies and P. R. Traill, Organometallics, 1998, 17, 2046-2051; D. G. Brown, P. K. Byers and A. J. Canty, Organometallics, 1990, 9, 3080-3085; B. A. Markies, A. J. Canty, J. Boersma and G. van Koten, Organometallics, 1994, 13, 2053-2058. 18 I. D. Rae, Can. J. Chem., 1966, 44, 1334.

19 F. Qu, J. R. Khusnutdinova, N. P. Rath and L. M. Mirica, Chem. Commun., 2014, 50, 3036-3039.

20 J. Vicente, A. Arcas, F. Julia-Hernandez and D. Bautista, Inorg. Chem., 2011, 50, 5339-5341.

21 P. K. Byers, A. J. Canty, B. W. Skelton and A. H. White, Organometallics, $1990,9,826$. 